\title{
Keanekaragaman dan Patogenisitas Fusarium spp. Asal Beberapa Kultivar Pisang
}

\author{
Diversity and Pathogenicity of Fusarium spp. \\ Isolated from Several Banana Cultivars
}

\author{
Widya Sari, Suryo Wiyono*, Ali Nurmansyah, Abdul Munif, Roedhy Poerwanto \\ Institut Pertanian Bogor, Bogor 16680
}

\begin{abstract}
ABSTRAK
Penyakit layu fusarium yang disebabkan oleh cendawan patogen Fusarium oxysporum f. sp. cubense merupakan penyakit penting pada tanaman pisang. Penelitian ini bertujuan mengidentifikasi spesies Fusarium yang diisolasi dari beberapa kultivar tanaman pisang bergejala layu secara morfologi dan molekuler. Isolat-isolat Fusarium yang diperoleh selanjutnya diuji tingkat patogenisitasnya, dan sebarannya pada berbagai bagian tanaman pisang. Berdasarkan pengamatan beberapa karakter morfologi (laju pertumbuhan, warna koloni, jumlah konidium, bentuk makrokonidium, mikrokonidium, dan klamidospora), F. oxysporum f. sp. cubense dapat dibedakan dengan spesies Fusarium yang lain akan tetapi tidak dapat membedakan ras atau galurnya. Hasil identifikasi molekuler menggunakan primer spesifik VCG 01213/16 dan Foc1/Foc2 diperoleh berturut-turut 13 isolat F. oxysporum f. sp. cubense TR4, dan 7 isolat $F$. oxysporum f. sp. cubense non TR4; sedangkan menggunakan primer universal ITS4/ITS5 diidentifikasi 7 isolat $F$. solani, 1 isolat $F$. verticillioides dan 2 isolat bukan Fusarium sp. Cendawan F. oxysporum f. sp. cubense TR4 dan non-TR4 banyak ditemukan di bagian batang semu tanaman pisang, sedangkan $F$. solani dan $F$. verticillioides dominan ditemukan di bonggol pisang. Uji patogenisitas menunjukkan bahwa isolat $F$. oxysporum $\mathrm{f}$. sp. cubense non TR4 dan TR4 mampu menimbulkan nekrosis pada bonggol bibit pisang kultivar Ambon Kuning. Gejala yang sama ditemukan pada hasil inokulasi $F$. solani tetapi dengan keparahan yang lebih rendah.
\end{abstract}

Kata kunci: batang semu, Fusarium oxysporum f. sp. cubense, kultivar Ambon Kuning, nekrosis

\begin{abstract}
Fusarium wilt disease caused by pathogenic fungus $F$. oxysporum $\mathrm{f}$. sp. cubense is an important disease in banana plants. This research was aimed to identifiy Fusarium spp. collected from banana plants showing wilt disease based on morphology and molecular characters. The fungi isolates obtained was further examined for its pathogenicity and distribution in various parts of banana plants. Based on morphological characters, i.e. growth rate, total conidia, colony color, macroconidium, microconidium, and chlamydospores, F. oxysporum f. sp. cubense can be differentiated from other species of Fusarium, but not the strain. Molecular analysis using specific primers VCG 01213/16 and Foc 1/Foc 2 successfully identified 13 and 7 isolates of $F$. oxysporum $\mathrm{f}$. sp. cubense TR 4 and $F$. oxysporum f. sp. cubense non TR4, respectively. Analysis using universal primer ITS4/ITS5 identified 7 isolates of $F$. solani, 1 isolate of $F$. verticillioides, and 2 isolates non Fusarium. Infection of $F$. oxysporum f. sp. cubense TR 4 and nonTR4 were found mostly in pseudo stems, whereas $F$. solani and $F$. verticillioides dominantly colonized
\end{abstract}

*Alamat penulis korespondensi: Departemen Proteksi Tanaman, Fakultas Pertanian, Institut Pertanian Bogor. Jalan Kamper, Kampus IPB Darmaga, Bogor 16680.

Tel: 0251-8629364, Faks: 0251-862362, Surel: suryowi@ipb.ac.id. 
banana corm. Pathogenicity test showed that $F$. oxysporum f. sp. cubense TR4 and non-TR4 caused necrosis on corm of cv. Ambon Kuning. Similar necrosis symptom was also observed on infection of $F$. solani but with less severity.

Key words: Ambon Yellow, F. oxysporum f. sp. cubense, necrosis, pseudo stem

\section{PENDAHULUAN}

Beberapa provinsi di Indonesia, di antaranya Sumatera Utara, Sumatera Barat dan Jawa Barat tercatat sebagai sentra produksi pisang (Kementan 2015). Jawa Barat berada di peringkat pertama sebagai produsen pisang pada tahun 2011. Sayangnya, produksi pisang dari Jawa Barat semakin menurun karena penyakit layu fusarium di beberapa kabupaten sentra produksi pisang, yaitu Cianjur, Majalengka, dan Bandung Barat (Pusdatin 2014).

Banyak faktor yang menyebabkan rendahnya produksi pisang di Indonesia salah satunya ialah penyakit layu yang disebabkan oleh cendawan $F$. oxyporum Schlecht f. sp cubense. Williams et al. (2010) melaporkan bahwa penyakit layu fusarium merupakan faktor utama penyebab menurunnya produksi pisang di Indonesia. Cendawan terdiri atas beberapa ras dan galur dengan tingkat virulensi yang berbeda, serta mempunyai kemampuan bertahan dalam tanah tanpa inang utama hingga 40 tahun (Ploetz 1990).

Penelitian penyakit layu fusarium pisang serta distribusi ras $F$. oxysporum f. $\mathrm{sp}$. cubense pada berbagai varietas dan lokasi sudah banyak dilakukan, termasuk distribusi VCG $F$. oxysporum f. sp. cubense pada beberapa kultivar pisang di beberapa provinsi di Indonesia. Williams et al. (2010) telah berhasil mengidentifikasi 8 kelompok VCG F. oxysporum f. sp. cubense $(0120 / 15,0121$, 0123, 0124/5, 0126, 01213/16, 01218 dan 01219) yang tersebar di Aceh, Sumatera Barat, Yogyakarta, Kalimantan Barat, Kalimantan Timur, Sulawesi Tenggara dan Sulawesi Utara. Semua VCG menyerang hampir semua varietas pisang, tapi varietas Barangan, Raja Bulu, dan Ambon Putih merupakan varietas dengan tingkat serangan tertinggi. F. oxysporum $\mathrm{f}$. sp. cubense VCG 01213/16 yang dikenal sebagai $F$. oxysporum f. sp. cubense ras 4 tropika
(TR4) merupakan kelompok yang paling dominan ditemukan Ploetz (2006). Leslie dan Summerell (2006) melaporkan terdapat lebih dari 10 Fusarium spp. yang berasosiasi dengan pisang di dunia, termasuk $F$. camptoceras, $F$. concentricum, F. musarum, $F$. proliferatum, $F$. semitectum (F. pallidoroseum, F. incarnatum), F. compactum, $F$. thapsinum, $F$. verticillioides, dan F. subglutinans.

Penelitian tentang beberapa spesies Fusarium yang berasosiasi dengan tanaman pisang bergejala layu, sebarannya pada beberapa kultivar dan bagian tanaman pisang serta pengujian patogenisitas dari masingmasing spesies tersebut pada pisang belum pernah dilakukan di Indonesia. Tujuan penelitian ini: menentukan karakter morfologi dan molekuler cendawan Fusarium spp. yang terdapat pada berbagai kultivar dan bagian tanaman pisang yang menunjukkan gejala layu; menentukan ras $F$. oxysporum f. sp. cubense dari berbagai kultivar pisang yang bergejala layu fusarium dan distribusinya pada bagian tanaman pisang; serta menentukan tingkat patogenisitasnya secara in planta pada pisang kultivar Ambon Kuning.

\section{BAHAN DAN METODE}

\section{Pengambilan Sampel di Lapangan}

Pengambilan sampel dilakukan di daerah endemik penyakit layu fusarium pada pisang, yaitu di Jawa Barat dan Sumatera Barat. Metode pengambilan sampel dilakukan secara komposit 8 desa di Kabupaten Cianjur Jawa Barat dan 2 desa di Sungai Lantik Kabupaten Lima Puluh Kota, Sumatera Barat dengan minimal luas lahan $100 \mathrm{~m}^{2}$. Sampel diambil dari bagian batang semu, bonggol dan akar tanaman pisang yang menunjukkan gejala layu. Sampel tanah diambil secara komposit pada 5 titik di rizosfer tanaman pisang. 


\section{Isolasi Fusarium spp.}

Jaringan batang semu dipotong dengan ukuran $0.5-1 \mathrm{~cm}$ sedangkan bonggol dan akar pisang sakit dipotong dengan ukuran $1 \times 1 \mathrm{~cm}$ kemudian disterilisasi permukaan dengan alkohol $70 \%$ dan dibilas akuades steril. Potongan sampel diletakkan pada medium agar-agar air (AA) dan diinkubasi selama 3-5 hari pada suhu kamar.

Isolasi Fusarium spp. dari tanah rizosfer dilakukan dengan membuat suspensi tanah dalam air steril dengan perbandingan 1:50 (b/v). Sebanyak $0.1 \mathrm{~mL}$ suspensi diteteskan di atas medium martin agar (Martin 1950), diratakan dengan gelas penyebar, dan diinkubasi pada suhu $27{ }^{\circ} \mathrm{C}$ selama $3-5$ hari. Koloni diamati menggunakan mikroskop. Koloni yang memiliki ciri spesifik Fusarium, yaitu mempunyai makrokonidium, mikrokonidium, dan klamidospora dimurnikan pada medium agar-agar dekstrosa kentang (ADK) komposisi $1 / 4$ resep untuk menjaga virulensinya dan disimpan untuk pengujian selanjutnya.

\section{Identifikasi Morfologi dan Molekuler Fusarium spp.}

Biakan Fusarium spp. diremajakan pada medium ADK komposisi $1 / 4$ resep (Dita et al. 2010)dan diinkubasi pada suhu ruang. Pengamatan dilakukan pada hari ke3, 5, dan 7 yang meliputi laju pertumbuhan koloni, warna koloni, kepadatan konidium (dihitung menggunakan haemositometer), bentuk makrokonidium, mikrokonida, dan klamidospora. Penghitungan laju pertumbuhan koloni menggunakan rumus laju pertumbuhan eksponensial, yaitu

$$
\mathrm{r}=\frac{1}{\mathrm{t}} \ln \left(\frac{\mathrm{Pt}}{\mathrm{Po}}\right) \text {, dengan }
$$

$\mathrm{r}$, laju pertumbuhan; $\mathrm{t}$, waktu pengamatan; $\mathrm{Pt}$, diameter koloni cendawan pada pengamatan terakhir; Po, diameter koloni cendawan pada pengamatan awal (Leslie dan Summerell 2006).

Idetifikasi molekuler semua isolat Fusarium spp. dilakukan dalam beberapa tahapan. Tahap awal ialah ekstraksi total DNA menggunakan sodium dodecyl sulfate (SDS) (Aamir et al. 2015) yang sudah dimodifikasi, dilanjutkan dengan amplifikasi DNA dengan teknik PCR. Bahan yang digunakan pada teknik PCR, yaitu DreamTaq PCR Master Mix (Thermoscientific ${ }^{\mathrm{TM}}$, US), 2 primer spesifik Foc 1/Foc2, 242 pb (Lin et al. 2009), dan F. oxysporum f. sp. cubense TR4-R, 462 pb (Dita et al. 2010) serta 1 primer universal ITS4 dan ITS5, $550 \mathrm{pb}$ (White et al. 1990). Hasil amplifikasi di elektroforesis menggunakan gel agarosa $2 \%$ dengan pewarnaan etidium bromida $\left(0.5 \mu \mathrm{g} \mathrm{mL}^{-1}\right)$ pada tegangan 100 volt selama 20 menit. Hasil visualisasi didokumentasi menggunakan geldoc digital imaging system (Gel imaging G:Box Chemi XX6, AlphaMetricBiotech, Germany (DE)).

Produk amplifikasi dengan primer universal ITS4 dan ITS5 selanjutnya disikuensing di PT Genetica Science Indonesia kemudian dibandingkan urutan DNA dengan yang lainnya menggunakan program BLAST dari National Center for Biotechnology Information (NCBI). Hasil sikuensing selanjutnya dilakukan penyejajaran menggunakan program Chromaspro versi 1.7.5. Analisis filogenetika menggunakan piranti lunak MEGA versi 6.0 untuk windows (Tamura et al. 2013).

\section{Patogenisitas pada Bibit Pisang}

Uji patogenisitas semua isolat dilakukan pada bibit pisang kultivar Ambon Kuning hasil kultur jaringan berumur 1.5 bulan setelah aklimatisasi. Pengujian ini menggunakan Rancangan Acak Lengkap (RAL) dengan 30 perlakuan dan 4 ulangan, perlakuan tersebut adalah 13 isolat Foc TR4, 7 isolat Foc non TR4, 1 isolat $F$. verticilloides, 7 isolat $F$. solani dan 2 isolat non Fusarium sebagai kontrol, yaitu isolat $T$. polyzona (isolat asal tanah rizosfer tanaman pisang kultivar Nangka) dan Clonostachys rosea (isolat asal batang tanaman pisang kultivar Ambon Kuning). Bibit pisang uji ditanam pada medium tanam campuran tanah dan kompos dengan perbandingan 2:1 (b/b). Medium tanam disterilisasi dan diinokulasi masing-masing $10 \mathrm{~g}$ biakan 30 isolat uji dalam medium beras dengan kerapatan konidia $10^{7} \mathrm{cfu} \mathrm{mL}^{-1}$.

Pengamatan diskolorasi pada bonggol dilakukan dengan memotong bonggol bibit 
umur 60 hari setelah inokulasi. Pengamatan keparahan penyakit diukur menggunakan skor sebagai berikut: 0 , tidak ada diskolorasi; 1, diskolorasi $0 \%<\mathrm{V} \leq 10 \%$; 2, diskolorasi $10 \%<\mathrm{V} \leq 33 \%$; 3, diskolorasi $33 \%<\mathrm{V} \leq 66 \%$; 4 , diskolorasi $66 \%<\mathrm{V} \leq 100 \%$; dan 5, diskolorasi 100\% (Corderio 1994).

\section{HASIL}

Penelitian ini menghasilkan 30 isolat yang berasal dari batang semu, bonggol, akar, dan tanah rizosfer. Sebanyak 21 isolat berasal dari kultivar Ambon Kuning, 5 isolat dari pisang Nangka, serta masing-masing 2 isolat berasal dari kultivar Raja Sereh dan Raja Bulu. Isolat terbanyak didapat dari batang semu pisang, yaitu sebanyak 14 isolat, sementara 10 isolat didapat dari bonggol, 2 isolat dari akar, dan 4 isolat dari tanah.

Berdasarkan pengamatan laju pertumbuhan, warna koloni, jumlah konidium, bentuk konidia dan klamidospora didapatkan Fusarium yang beragam. Beberapa memiliki ciri khas $F$. oxysporum (Isolat BG2, BT3, BG6, BT11, BT14A, BT14B, BT14C, BT15, BT17, BT18, BT18C, TA23A, A24, BG10B, BT12, BT16A, BT16B, BT16C, BT28, BT29); dan $F$. solani (isolat BG1, BG4, BG10A, A19, A20, A21, TA23) serta 1 isolat BG7 mempunyai ciri makro dan mikro konidium yang berbeda dengan $F$. oxysporum dan $F$. solani (Tabel 1).

Kisaran laju pertumbuhan semua isolat adalah $0.17-0.38 \mathrm{~cm}$ per hari (Gambar 1). Beberapa islat dari $F$. oxysporum f. sp. cubense (BG2, BT3A, BT12, BT14A, BT14B, BT16A, BT16B), dan beberapa isolat $F$. solani (BG1, BG4, BG10A) serta isolat BG7 ( $F$. verticilloides) mempunyai laju pertumbuhan yang lebih tinggi dibanding dari isolat lainnya.

Warna koloni untuk setiap kelompok Fusarium spp. didominasi oleh warna putih, tetapi beberapa isolat $F$. oxysporum f. sp. cubense non TR4 dan TR4 juga memiliki warna koloni merah muda, ungu muda, dan krem. Tipe koloni didominasi oleh tipe seperti kapas dan tipis. Pada masing-masing isolat Fusarium spp. terdapat sporodokium.
Cendawan $F$. oxysporum mempunyai makrokonidium dan mikrokonidium dengan karakter yang berbeda dengan isolat $F$. solani. Makrokonidium $F$. oxysporum berbentuk seperti bulan sabit dengan beberapa sekat, mikrokonidium berbentuk oval atau seperti ginjal, serta fialid ada yang tunggal atau bercabang. Mikrokonidium terbentuk pada fialid. Ada yang tunggal, berkelompok pada ujung fialid dan tersusun seperti rantai. Klamidospora berbentuk bulat, berdinding tebal, terbentuk di ujung hifa, di tengah hifa atau makrokonidium dan bisa tersusun seperti rantai.

Makrokonidium $F$. oxysporum f. $\mathrm{sp}$. cubense memiliki ukuran $27-55 \times 3.3-5.5 \mu \mathrm{m}$, sel berbentuk lurus atau sedikit bengkok dengan 4-8 sekat dengan ujung atas runcing dan tujung bawah datar. Mikrokonidium berbentuk bulat atau menyerupai ginjal, berukuran 5-16 $\times$ 2.4-3.5 $\mu \mathrm{m}$, memiliki 1 atau 2 sekat. Fialid dan mikrokonidium berkelompok dengan ujung miring ke kiri. Klamidospora berdiameter 7-11 $\mu \mathrm{m}$, berbentuk bulat secara tunggal atau berantai. $F$. solani dibedakan dengan $F$. oxysporum berdasarkan karakteristik bentuk makrokonidium juga bentuk mikrokonidium yang relatif lebih besar untuk $F$. solani dan mikrokonidium umumnya berbentuk elips (Gambar 2).

Secara umum kepadatan kondium berkisar 7.71-9.4 $\mathrm{cm}^{-2}$ (data dikonversi menggunakan $\log 10)$. Analisis molekuler pada 30 isolat menggunakan primer Foc $1 /$ Foc 2 berhasil mengamplifikasi 7 isolat $F$. oxysporum $\mathrm{f}$. sp. cubense nonTR4 dengan ukuran $\sim 242 \mathrm{pb}$, sedangkan amplifikasi menggunakan primer FocTR 4 menghasilkan 13 isolat positif $F$. oxysporum f. sp. cubense TR4 berukuran $\sim 462 \mathrm{pb}$ (Gambar 3). Penentuan ras $F$. oxysporum f. sp. cubense nonTR4 dilakukan dengan cara membandingkan hasil amplifikasi kedua primer spesifik $F$. oxysporum f. sp. cubense yang digunakan. Apabila dapat diamplifikasi oleh kedua primer $F$. oc1/ Foc 2 dan TR4, berarti isolat merupakan $F$. oxysporum f. sp. cubense TR4, begitu juga bila hanya teramplifikasi pada primer TR4 saja. Tetapi apabila hanya teramplifikasi oleh 
Tabel 1 Identifikasi morfologi isolat Fusarium spp. asal beberapa kultivar dan bagian tanaman pisang

\begin{tabular}{|c|c|c|c|c|c|c|}
\hline \multirow[b]{2}{*}{ Isolat } & \multicolumn{2}{|r|}{ Koloni } & \multicolumn{3}{|c|}{ Konidium } & \multirow[b]{2}{*}{ Klamidospora } \\
\hline & Warna & $\begin{array}{l}\text { Laju pertumbuhan } \\
\left(\mathrm{cm} \mathrm{Hr}^{-1}\right)\end{array}$ & Makro & Mikro & $\begin{array}{c}\text { Kepadatan } \\
\text { Konidia }^{\text {a) }}\end{array}$ & \\
\hline BT3A & putih & 0.96 & $\begin{array}{l}\text { Melengkung, } \\
\text { ujung runcing, } \\
\text { sekat 2-3 }\end{array}$ & $\begin{array}{l}\text { Oval, sekat } \\
\quad 0-1\end{array}$ & 7.72 & $\sqrt{ } \mathrm{b})$ \\
\hline BT11 & Krem & 0.96 & $\begin{array}{l}\text { Melengkun, } \\
\text { ujung tumpul, } \\
\text { sekat 2-3 }\end{array}$ & $\begin{array}{l}\text { Oval, sekat } \\
\quad 0-1\end{array}$ & 7.26 & $\sqrt{ }$ \\
\hline BT12 & putih & 0.99 & $\begin{array}{l}\text { Melengkung, } \\
\text { ujung runcing, } \\
\text { sekat } 1-3\end{array}$ & $\begin{array}{l}\text { Oval, sekat } \\
\quad 0-1\end{array}$ & 8.16 & $\sqrt{ }$ \\
\hline BT14A & Krem & 1.09 & $\begin{array}{l}\text { Melengkung, } \\
\text { ujung runcing, } \\
\text { sekat } 1-3\end{array}$ & $\begin{array}{c}\text { Meleng } \\
\text { kung, sekat } \\
0-1\end{array}$ & 8.12 & $\sqrt{ }$ \\
\hline BT14B & Putih & 1.13 & $\begin{array}{l}\text { Melengkung, } \\
\text { ujung runcing, } \\
\text { sekat } 1-3\end{array}$ & $\begin{array}{c}\text { Meleng } \\
\text { kung, sekat } \\
0-1\end{array}$ & 5.65 & $\sqrt{ }$ \\
\hline BT14C & Putih & 1.20 & $\begin{array}{l}\text { Melengkung, } \\
\text { ujung runcing, } \\
\text { sekat 1-3 }\end{array}$ & Oval, sekat 0 & 7.70 & $\sqrt{ }$ \\
\hline BT15 & Putih & 0.59 & $\begin{array}{l}\text { Melengkung, } \\
\text { ujung runcing, } \\
\text { sekat } 3\end{array}$ & $\begin{array}{l}\text { Bulat, sekat } \\
\quad 0\end{array}$ & 8.34 & $\sqrt{ }$ \\
\hline BT16A & $\begin{array}{l}\text { Ungu } \\
\text { pucat }\end{array}$ & 0.91 & $\begin{array}{l}\text { Melengkung, } \\
\text { ujung runcing, } \\
\text { sekat } 2-3\end{array}$ & $\begin{array}{c}\text { Bulat dan } \\
\text { oval, sekat } 0\end{array}$ & 7.96 & $\sqrt{ }$ \\
\hline BT16B & Putih & 1.02 & $\begin{array}{l}\text { Melengkung, } \\
\text { ujung runcing, } \\
\text { sekat } 2-3\end{array}$ & $\begin{array}{c}\text { Bulat dan } \\
\text { oval, sekat } 0\end{array}$ & 7.29 & $\sqrt{ }$ \\
\hline BT16C & Putih & 1.02 & $\begin{array}{l}\text { Melengkung, } \\
\text { ujung runcing, } \\
\text { sekat } 1-3\end{array}$ & $\begin{array}{c}\text { Bulat dan } \\
\text { oval, sekat } 0\end{array}$ & 8.00 & $\sqrt{ }$ \\
\hline BT17 & $\begin{array}{l}\text { Ungu } \\
\text { pucat }\end{array}$ & 1.03 & $\begin{array}{l}\text { Melengkung, } \\
\text { ramping, } \\
\text { ujung runcing } \\
\text { mengait, sekat } 3\end{array}$ & $\begin{array}{l}\text { Oval, sekat } \\
0-1\end{array}$ & 7.87 & $\sqrt{ }$ \\
\hline BT28 & Putih & 1.14 & $\begin{array}{l}\text { Melengkung, } \\
\text { ujung runcing } \\
\text { mengait, sekat } 3\end{array}$ & $\begin{array}{c}\text { Panjang } \\
\text { oval, sekat } 0\end{array}$ & 8.01 & $\sqrt{ }$ \\
\hline BT29 & Putih & 0.99 & $\begin{array}{l}\text { Melengkung, } \\
\text { ujung tumpul, } \\
\text { sekat } 2\end{array}$ & $\begin{array}{c}\text { Oval, } \\
\text { melengkung, } \\
\text { sekat } 1\end{array}$ & 8.56 & $\sqrt{ }$ \\
\hline BG1 & Putih & 0.87 & $\begin{array}{l}\text { Melengkung, } \\
\text { ujung tumpul, } \\
\text { sekat } 2-3\end{array}$ & $\begin{array}{l}\text { Oval besar, } \\
\text { sekat } 0-1\end{array}$ & 7.74 & $\sqrt{ }$ \\
\hline BG2 & Putih & 0.99 & $\begin{array}{l}\text { Melengkung, } \\
\text { ujung runcing, } \\
\text { sekat } 2-3\end{array}$ & Oval, sekat 1 & 8.10 & $\sqrt{ }$ \\
\hline
\end{tabular}

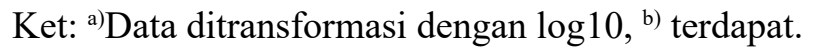


...Lanjutan Tabel 1

\begin{tabular}{|c|c|c|c|c|c|c|}
\hline \multirow[b]{2}{*}{ Isolat } & \multicolumn{2}{|r|}{ Koloni } & \multicolumn{3}{|c|}{ Konidium } & \multirow[b]{2}{*}{ Klamidospora } \\
\hline & Warna & $\begin{array}{l}\text { Laju pertumbuhan } \\
\left.\text { ( } \mathrm{cm} \mathrm{Hr}^{-1}\right)\end{array}$ & Makro & Mikro & $\begin{array}{l}\text { Kepadatan } \\
\text { Konidia }^{\text {a) }}\end{array}$ & \\
\hline BG4 & Putih & 0.73 & $\begin{array}{l}\text { Melengkung, } \\
\text { ujung tumpul, } \\
\text { sekat 2-3 }\end{array}$ & $\begin{array}{l}\text { Oval besar, } \\
\text { sekat } 0-1\end{array}$ & 7.98 & $\sqrt{ }$ \\
\hline BG6 & Putih & 1.00 & $\begin{array}{l}\text { Melengkung, } \\
\text { ujung runcing, } \\
\text { sekat 2-3 }\end{array}$ & $\begin{array}{l}\text { Berbentuk } \\
\text { ginjal, sekat } \\
1\end{array}$ & 7.85 & $\sqrt{ }$ \\
\hline BG7 & $\begin{array}{l}\text { Merah } \\
\text { muda }\end{array}$ & 0.90 & $\begin{array}{l}\text { Panjang, sedikit } \\
\text { melengkung, } \\
\text { ujung Runcing, } \\
\text { sekat } 3\end{array}$ & $\begin{array}{l}\text { Memanjang, } \\
\text { sekat } 1\end{array}$ & 7.91 & - \\
\hline BG10A & Putih & 1.02 & $\begin{array}{l}\text { Melengkung, } \\
\text { ujung tumpul, } \\
\text { sekat } 2\end{array}$ & $\begin{array}{l}\text { Oval, } \\
\text { melengkung, } \\
\text { sekat } 1\end{array}$ & 7.01 & $\sqrt{ }$ \\
\hline BG10B & $\begin{array}{l}\text { Ungu } \\
\text { pucat }\end{array}$ & 1.14 & $\begin{array}{l}\text { Melengkung, } \\
\text { ujung runcing, } \\
\text { sekat 2-3 }\end{array}$ & $\begin{array}{l}\text { Memanjang, } \\
\text { sekat } 0\end{array}$ & 7.60 & $\sqrt{ }$ \\
\hline BG18 & Putih & 1.10 & $\begin{array}{l}\text { Melengkung, } \\
\text { ujung tumpul, } \\
\text { sekat } 2\end{array}$ & $\begin{array}{l}\text { Oval, } \\
\text { melengkung, } \\
\text { sekat } 1\end{array}$ & 7.59 & $\sqrt{ }$ \\
\hline BG18C & Krem & 1.14 & $\begin{array}{l}\text { Melengkung, } \\
\text { ujung runcing, } \\
\text { sekat } 3\end{array}$ & $\begin{array}{l}\text { Panjang } \\
\text { oval, sekat } 0\end{array}$ & 7.07 & $\sqrt{ }$ \\
\hline A19 & Putih & 1.14 & $\begin{array}{l}\text { Melengkung, } \\
\text { ujung tumpul, } \\
\text { sekat 2-3 }\end{array}$ & $\begin{array}{l}\text { Oval besar, } \\
\text { sekat } 0-1\end{array}$ & 7.47 & $\sqrt{ }$ \\
\hline A20 & Putih & 1.14 & $\begin{array}{l}\text { Melengkung, } \\
\text { ujung tumpul, } \\
\text { sekat } 3\end{array}$ & Oval, sekat 0 & 7.73 & $\sqrt{ }$ \\
\hline TA21 & Putih & 1.14 & $\begin{array}{l}\text { Melengkung, } \\
\text { ujung tumpul, } \\
\text { sekat 2-3 }\end{array}$ & $\begin{array}{l}\text { Oval besar, } \\
\text { sekat } 0-1\end{array}$ & 8.05 & $\sqrt{ }$ \\
\hline TA23 & Krem & 1.12 & $\begin{array}{l}\text { Melengkung, } \\
\text { ujung runcing, } \\
\text { sekat } 3\end{array}$ & Oval, sekat 1 & 7.74 & $\sqrt{ }$ \\
\hline TA23A & Putih & 1.10 & $\begin{array}{l}\text { Melengkung, } \\
\text { ujung runcing, } \\
\text { sekat } 3\end{array}$ & Oval, sekat 1 & 7.84 & $\sqrt{ }$ \\
\hline TA24 & Putih & 1.10 & $\begin{array}{l}\text { Melengkung, } \\
\text { ujung runcing, } \\
\text { sekat } 3\end{array}$ & Oval, sekat 1 & 7.84 & $\sqrt{ }$ \\
\hline
\end{tabular}

Ket: ${ }^{a}$ Data ditransformasi dengan $\log 10$, ${ }^{\text {b) }}$ terdapat.

primer Foc1/Foc2, dapat diasumsikan bahwa isolat-isolat tersebut positif $F$. oxysporum $\mathrm{f}$. sp. cubense ras 1 atau ras 2. Pada penelitian ini tidak dilakukan analisis VCG sehingga tidak didapatkan VCG spesifik yang merujuk pada ras-ras $F$. oxysporum f. sp. cubense lainnya.
Hasil BLAST-N dari sikuen produk PCR dengan primer ITS4 dan ITS5 yang teramplifikasi pada $\sim 550$ pb menghasilkan 7 isolat yang identik dengan $F$. solani, satu isolat $F$. verticillioides sedangkan dua isolat terakhir, yaitu isolat TA25 dan BT26 tidak 


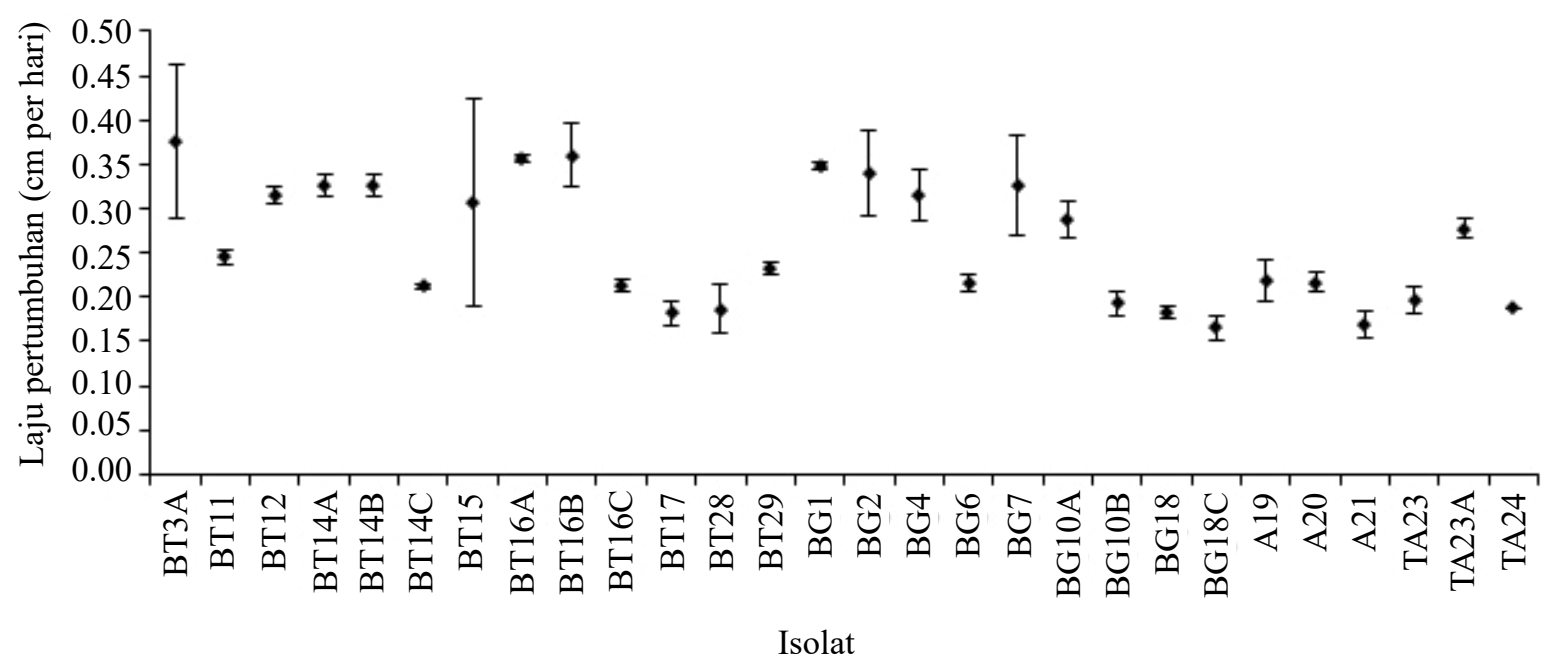

Gambar 1 Laju pertumbuhan isolat cendawan yang berasal dari berbagai kultivar dan bagian tanaman pisang.

Fusarium f.sp. cubense
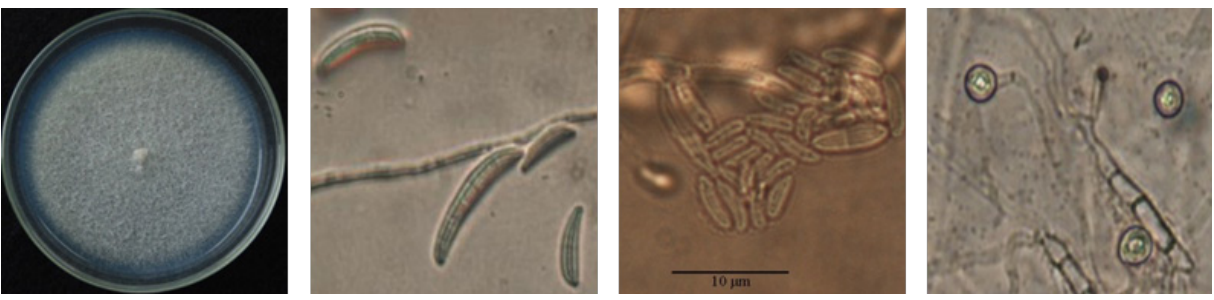

Fusarium solani
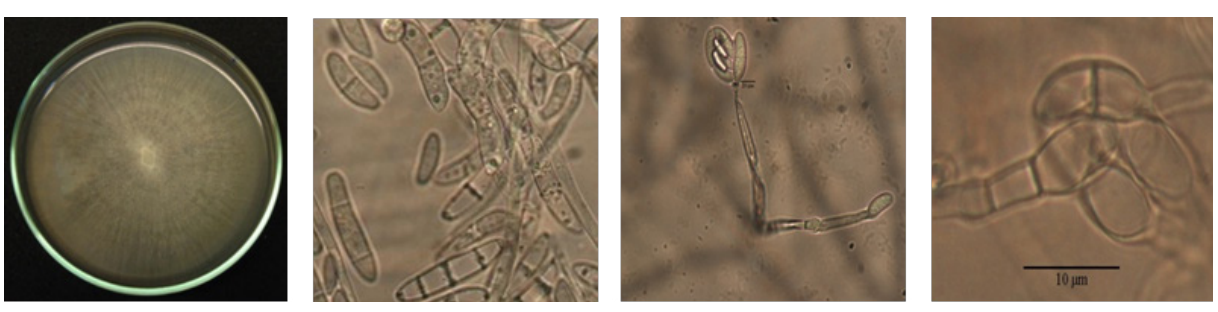

Fusarium sp.

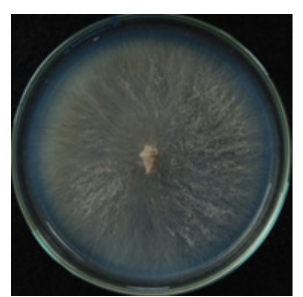

Bentuk koloni

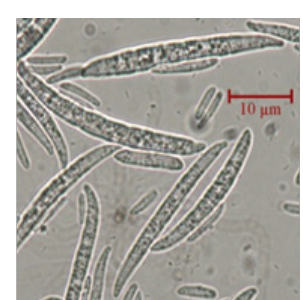

Makrokonidia

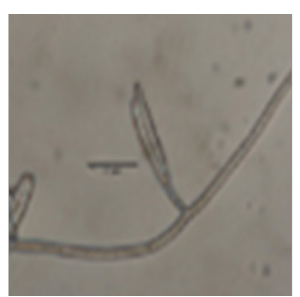

Mikrokonidia

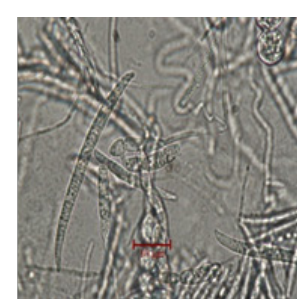

Klamidospora

Gambar 2 Karakter morfologi Fusarium spp yang diamati pada pembesaran 100×.

termasuk genus Fusarium (Tabel 2; Gambar 4). Berdasarkan sumber isolatnya terdapat kecenderungan bahwa isolat $F$. oxysporum $\mathrm{f}$. sp. cubense nonTR4, F. oxysporum f. sp. cubense TR4, dan F. solani dominan ditemukan pada pisang kultivar Ambon Kuning, yaitu 7 isolat F. oxysporum f. sp. cubense nonTR4 (5 isolat dari batang semu, 1 isolat dari bonggol, dan 1 isolat dari rizosfer), 9 isolat $F$. oxysporum $\mathrm{f}$. sp. cubense TR4 (6 isolat pada batang semu,
1 isolat pada bonggol dan 2 isolat dari rizofer) dan 4 isolat $F$. solani (2 isolat dari bonggol, 1 isolat dari akar dan 1 isolat dari rizosfer). Pada kultivar Raja Bulu ditemukan 2 isolat F. oxysporum f. sp. cubense TR4 (1 isolat dari batang semu dan 1 isolat dari bonggol), pada kultivar Raja Sereh ditemukan 1 isolat F. oxysporum f. sp. cubense non TR4 dari batang semu dan 1 isolat $F$. verticiollioides, dan pada Kultivar Nangka ditemukan 2 isolat 


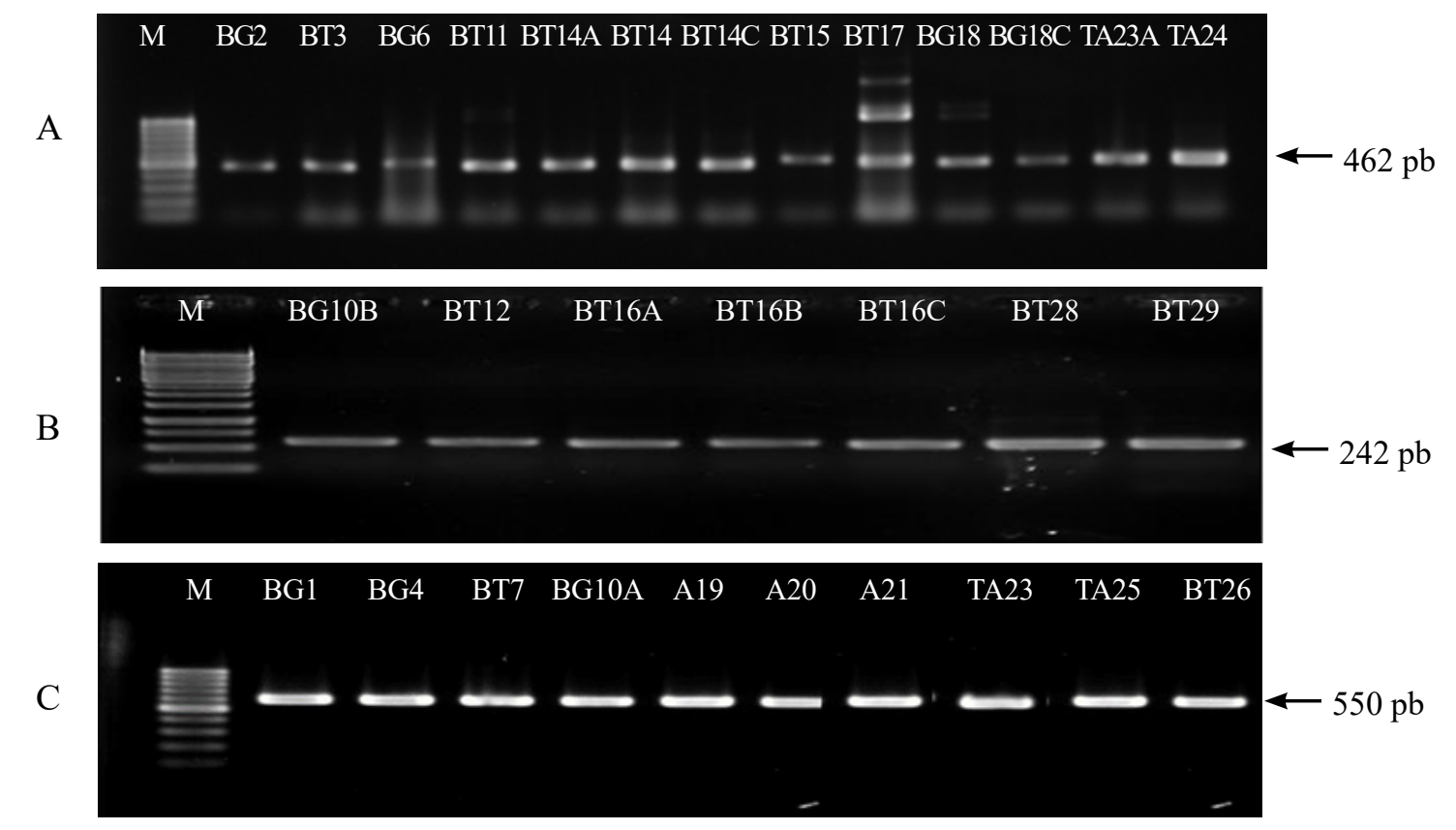

Gambar 3 Hasil amplifikasi isolat Fusarium spp. A, F. oxysporum f. sp. cubense TR4 menggunakan primer FocTR4 (Isolat BG2, BT3, BG6, BT11, BT14A, BT14B, BT14C, BT15, BT17, BG18, BG18C, TA23A, TA24); B, F. oxysporum f. sp. cubense non TR4 menggunakan primer Foc1/Foc2 (Isolat BG10B, BGT12, BT16A, BT16B, BT16C, BT28, BT29); C, Fusarium spp. dan non Fusarium menggunakan primer ITS4 dan ITS5 (ISOLAT BG1,BG 4, BT7, BGT10A, A19, A20, A21, TA23, TA25, BT26); M, Penanda 1 kb (Thermo scientific).

Tabel 2 Tingkat homologi sikuen nukleotida isolat non Fusarium oxysporum f. sp. cubense berdasarkan ITS yang dibandingkan data GenBank NCBI

\begin{tabular}{llccc}
\hline Isolat & \multicolumn{1}{c}{ Deskripsi } & $\begin{array}{c}\text { Query Cover } \\
(\%)\end{array}$ & $\begin{array}{c}\text { Identitas } \\
(\%)\end{array}$ & No Aksesi \\
\hline BG1 & Fusarium solani BG1 & 99 & 100 & FJ224382.1 \\
BG4 & Fusarium solani BG4 & 99 & 100 & FJ224382.1 \\
BG10A & Fusarium solani BG10A & 99 & 100 & FJ224382.1 \\
A19 & Fusarium sp. A19 & 100 & 99 & EU750681.1 \\
A20 & Fusarium sp. A20 & 100 & 99 & EU750681.1 \\
A21 & Fusarium sp. A21 & 100 & 99 & EU750681.1 \\
TA23 & Fusarium solani TA23 & 99 & 100 & JQ277276.1 \\
BG7 & Fusarium verticillioides BG7 & 100 & 100 & KM434131.1 \\
TA25 & Trametes polyzona TA25 & 100 & 99 & JN164978.1 \\
BT26 & Clonostachys rosea BT26 & 100 & 99 & HQ607798.1 \\
\hline
\end{tabular}

F. oxysporum f. sp. cubense TR4 dan 2 isolat F. solani.

Hasil uji patogenisitas isolat Fusarium spp. yang sudah dikarakteriasi secara morfologi dan molekuler pada bibit pisang Ambon Kuning menunjukkan bahwa beberapa isolat F. oxysporum f. sp. cubense nonTR4 dan TR4 mampu menimbulkan nekrosis pada bonggol pisang Ambon kuning dengan skala keparahan yang bervariasi. Beberapa isolat $F$. oxysporum f. sp. cubense nonTR4 (isolat BT12, BT29) mempunyai nilai skala keparahan nekrosis yang lebih tinggi dibandingkan dengan isolat F. oxysporum f. sp. cubense TR4. Isolat BG2 merupakan isolat $F$. oxysporum $\mathrm{f}$. sp. cubense TR4 yang memiliki nilai skala keparahan yang lebih tinggi dibanding dengan $F$. oxysporum $\mathrm{f}$. sp. cubense TR4 lainnya.

Isolat F. solani (BG1 dan BG4) mampu menimbulkan gejala nekrosis yang sama 


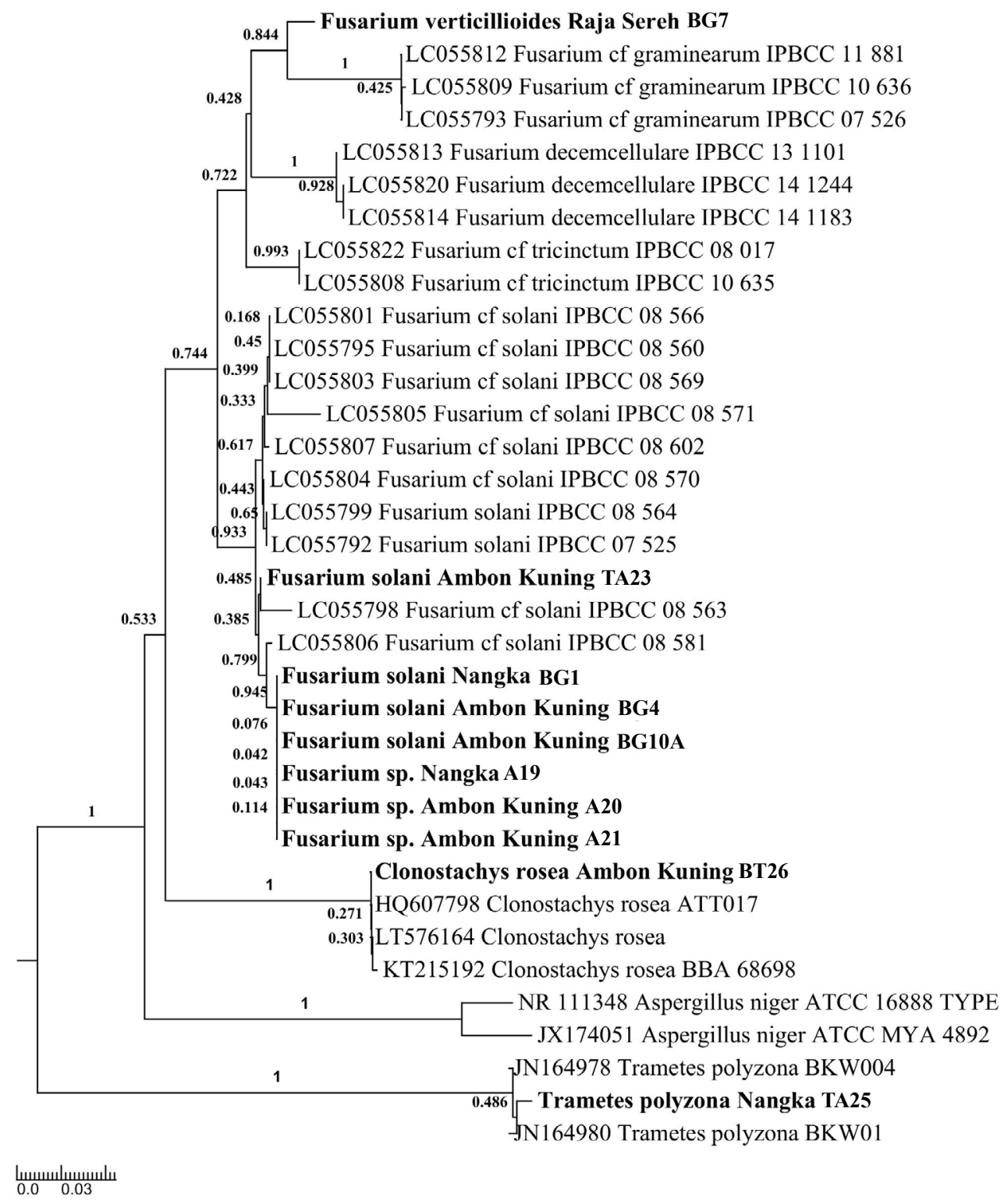

Gambar 4 Pohon filogenetika analisis sikuen nukleotida daerah ITS menggunakan metode neigbour-joining dan model jukes and cantor. Nilai Bootstrap 1000. Huruf yang dicetak tebal menunjukkan isolat yang diteliti.

dengan yang ditimbulkan $F$. oxysporum f. sp. cubense, walaupun dengan tingkat keparahan yang lebih rendah (Tabel 3; Gambar 5). Sementara itu pengujian dengan F. verticillioides (Isolat BG7) memperlihatkan sedikit perubahan warna pada bonggol bibit pisang tetapi belum sampai menyebabkan nekrosis pada bonggol bibit pisang.

\section{PEMBAHASAN}

Fusarium spp. merupakan cendawan yang mempunyai sebaran inang luas. $F$. oxysporum f. sp. cubense merupakan 1 dari 6 patogen yang menyerang pembuluh tanaman dan sangat merugikan komoditi pertanian di dunia. Cendawan ini tersebar luas pada daerah penghasil pisang di Asia, Afrika, Australia, dan Amerika Tengah serta Selatan yang mampu mematikan tanaman pisang yang terserang (Hwang dan Ko 2014). Pada penelitian ini cendawan Fusarium spp. ditemukan pada bagian tanaman pisang yang sakit (bonggol, batang semu, akar, dan tanah rizosfer). Mikrokonidium Fusarium biasa berada di dalam jaringan pembuluh tanaman 
Tabel 3 Skoring diskolorasi pada potongan bonggol bibit pisang Ambon Kuning setelah diinokulasi dengan isolat Fusarium spp. asal bagian tanaman pisang dari kultivar yang berbeda

\begin{tabular}{|c|c|c|c|c|}
\hline Isolat & $\begin{array}{l}\text { Asal bagian tanaman dan } \\
\text { kultivar pisang }\end{array}$ & Spesies & Ras & Skora) \\
\hline BG10B & Bonggol, Ambon Kuning & F. oxysporum f.sp. cubense & non TR4 & $1-2$ \\
\hline BT12 & Batang, Raja Sereh & F. oxysporum f.sp. cubense & non TR4 & $2-3$ \\
\hline BT16A & Batang, Ambon Kuning & F. oxysporum f.sp. cubense & non TR4 & $1-2$ \\
\hline BT16B & Batang, Ambon Kuning & F. oxysporum f.sp. cubense & non TR4 & $1-2$ \\
\hline BT16C & Batang, Ambon Kuning & F. oxysporum f.sp. cubense & non TR4 & $0-1$ \\
\hline TA23A & Rizosfer, Ambon Kuning & F. oxysporum f.sp. cubense & non TR4 & $1-2$ \\
\hline BT28 & Batang, Ambon Kuning & F. oxysporum f.sp. cubense & non TR4 & $1-2$ \\
\hline ВТ29 & Batang, Ambon Kuning & F. oxysporum f.sp. cubense & non TR4 & $1-3$ \\
\hline BG2 & Bonggol, Ambon Kuning & F. oxysporum f.sp. cubense & TR4 & $1-4$ \\
\hline BT3 & Batang, Ambon Kuning & F. oxysporum f.sp. cubense & TR4 & $1-2$ \\
\hline BG6 & Bonggol, Raja Bulu & F. oxysporum f.sp. cubense & TR4 & $1-2$ \\
\hline BT11 & Batang, Raja Bulu & F. oxysporum f.sp. cubense & TR4 & $0-2$ \\
\hline BT14A & Batang, Ambon Kuning & F. oxysporum f.sp. cubense & TR4 & $0-1$ \\
\hline BT14B & Batang, Ambon Kuning & F. oxysporum f.sp. cubense & TR4 & $0-1$ \\
\hline BT14C & Batang, Ambon Kuning & F. oxysporum f.sp. cubense & TR4 & $0-1$ \\
\hline BT15 & Batang, Ambon Kuning & F. oxysporum f.sp. cubense & TR4 & $0-1$ \\
\hline BT17 & Batang, Ambon Kuning & F. oxysporum f.sp. cubense & TR4 & $0-1$ \\
\hline BG18 & Bonggol, Nangka & F. oxysporum f.sp. cubense & TR4 & $0-1$ \\
\hline BG18C & Bonggol, Nangka & F. oxysporum f.sp. cubense & TR4 & $1-2$ \\
\hline TA23 & Rizosfer, Ambon Kuning & F. oxysporum f.sp. cubense & TR4 & $1-2$ \\
\hline TA24 & Rizosfer, Ambon Kuning & F. oxysporum f.sp. cubense & TR4 & $1-2$ \\
\hline BG1 & Bonggol & F. solani & - & $1-2$ \\
\hline BG4 & Bonggol & F. solani & - & $0-2$ \\
\hline BG10A & Bonggol & F. solani & - & $0-1$ \\
\hline A19 & Akar, Nangka & F. solani & - & 0 \\
\hline A20 & Akar, Ambon Kuning & F. solani & - & $0-2$ \\
\hline A 21 & Akar, Ambon Kuning & F. solani & - & 0 \\
\hline BG7 & Bonggol, Raja Serai & F. verticilioides & - & $0-1$ \\
\hline
\end{tabular}

${ }^{a}$ Skor keparahan penyakit : 0 , tidak ada diskolorasi; 1, diskolorasi $0<\mathrm{V} \leq 10 \%$; , diskolorasi $10 \%<\mathrm{V} \leq 33 \%$; 3, diskolorasi 33\%<V $\leq 66 \%$; 4, diskolorasi $66 \%<\mathrm{V} \leq 100 \%$; dan 5, diskolorasi $100 \%$.

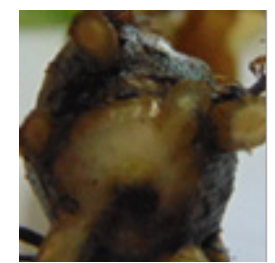

1

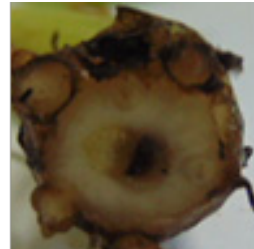

2

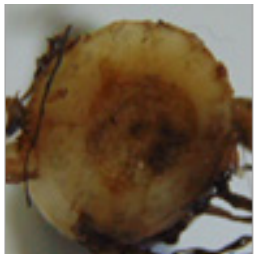

3

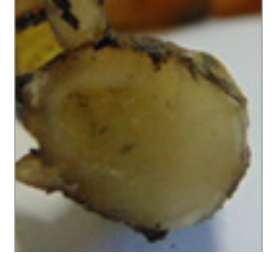

4

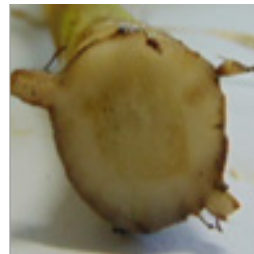

5

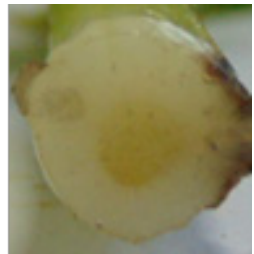

6

Gambar 5 Gejala nekrotik pada bonggol bibit pisang yang diinokulasi beberapa isolat Fusarium spp. pada 60 hari setelah inokulasi. 1, F. oxysporum f. sp. cubense non TR4; 2, F. oxysporum f. sp. cubense TR4; 3, F. solani; 4, Kontrol 1 (Trametes polyzona Nangka Ta25); 5, Kontrol 2 (Clonostachys rosea Ambon Kuning Bt26); 6, Kontrol 3 (tanpa isolat).

pisang. Sporodokium, makrokonidium dan klamidospora sering ditemukan pada permukaan pangkal pelepah dan sisa tanaman. Klamidospora umumnya ditemukan di tanah karena merupakan spora bertahan apabila tanaman inang tidak ditemukan (Dita et al. 2010).

Secara morfologi Fusarium spp. dapat dikenali berdasarkan bentuk makrokonidium, struktur konidiofor mikrokonidium, panjang 
fialid, pembentukan dan posisi klamidospora. Meskipun pengamatan morfologi tidak cukup untuk identifikasi lengkap, tapi banyak informasi yang dapat diperoleh saat biakan di medium kultur. Hasil pengamatan bentuk makrokonidium dan mikrokonidium menunjukkan adanya perbedaan spesifik antara $F$. oxysporum, Fusarium solani, $F$. verticillioides, $T$. polyzona dan C. rosea. $T$. polyzona merupakan cendawan tanah yang berasal dari rizosfer tanaman pisang kultivar Nangka dan $C$. rosea merupakan isolat yang berasal dari batang tanaman pisang kultivar Ambon Kuning. Kedua cendawan ini mempunyai karakter morfologi yang berbeda dengan Fusarium spp., dimana keduanya tidak memiliki makro dan mikrokonidia. T. polyzona mempunyai konidia dengan ukuran yang sangat kecil dibanding dengan mikrokonidia Fusarium spp. Ciri khas dari $F$. oxysporum mempunyai makrokonidium yang sedikit bengkok dengan ujung runcing, terdiri atas 3-4 sekat. Mikrokonidium yang berbentuk oval atau seperti ginjal, tanpa sekat dan terbentuk pada ujung fialid yang bertangkai pendek. Sedangkan $F$. solani mempunyai makrokonidium yang besar dan tumpul terdiri dari 3-4 sekat, dengan mikrokonidium yang berbentuk oval (dengan atau tanpa sekat) dan terbentuk pada ujung tangkai fialid yang panjang.F.oxysporum dan F. solanimempunyai klamidospora yang tersusun dalam satu rantai atau terdapat pada ujung dan tengah hifa. $F$. verticilliodes mempunyai makrokonidium yang lurus, panjang dan langsing, dengan sekat 3-5. Mikrokonidium berbentuk oval dan tanpa sekat. $F$. verticilliodes tidak mempunyai klamidospora.

Karakter morfologi laju pertumbuhan dan kerapatan konidium, warna dan tipe koloni yang didapatkan sangat bervariasi. Khususnya laju pertumbuhan dan kerapatan konidia tidak bisa dipakai sebagai acuan pembeda. Tetapi bentuk dan warna koloni memperlihatkan karakter yang berbeda diantara spesies. $F$. oxysporum umumnya mempunyai warna koloni putih, krem, dan ungu pucat, sedangkan $F$. solani didominasi oleh warna koloni putih. $F$. verticillioides berwarna merah muda dan genus non fusarium mempunyai warna putih. Menurut Ploetz (1990) variasi warna pada F. oxysporum pada medium bisa disebabkan kondisi dan medium kultur yang digunakan.

Data karakter morfologi yang diperoleh belum bisa menunjukkan isolat $F$. oxysporum f. sp. cubense TR4 dan non TR4 karena secara umum bentuk makrokonidium dan mikrokonidium, warna koloni dan posisi klamidospora yang sama. Menurut O’Donnell et al. (2008) karakterisasi secara morfologi tidak bisa menggambarkan hubungan kekerabatan antarspesies bahkan antarras, juga tidak bisa digunakan untuk membedakan patogenisitas dari masing-masing spesies atau ras.

Identifikasi secara molekuler menggunakan primer spesifik dan universal primer dapat menyalin urutan basa DNA dari suatu organisme sehingga dapat digunakan untuk identifikasi sampai tingkat ras atau strain. Hasil karakterisasi secara molekuler terhadap 30 isolat Fusarium spp terlihat bahwa $F$. oxysporum f. sp. cubense TR 4 (13 isolat) paling banyak ditemukan, diikuti oleh $F$. oxysporum f. sp. cubense non TR4 (7 isolat ) dan F. solani (7 isolat) dan F. verticillioides. Hal ini menunjukkan bahwa sebaran $F$. oxysporum f. sp. cubense TR4 sudah meluas dan mendominasi di daerah pengambilan sampel. Hermanto et al. (2011) juga menemukan $F$. oxysporum f. sp. cubense TR4 sudah menyebar di hampir semua provinsi Indonesia dan menyerang hampir semua varietas pisang lokal yang bergenom AA (Rejang), AAA (Ambon Kuning, Ambon Hijau, Barangan), AAB (Ketan, Raja Bulu, Raja Sereh), dan ABB (Awak, Kepok).

Fusarium spp. mempunyai kisaran inang luas dan keragaman morfologi serta patogenisitas yang bervariasi. Sampai saat ini belum ada metode sederhana untuk membedakan antara strain patogenik dan nonpatogenik pada Fusarium spp (Alabouvette dan Couteaudier 1992). Hanya inokulasi pada tanaman inang yang dapat digunakan untuk menentukan sifat patogenik atau nonpatogenik Fusarium. Strain yang tidak dapat menyebabkan gejala pada tanaman dianggap sebagai nonpatogenik untuk tanaman tersebut. 
Secara alami Fusarium menyerang jaringan tanaman yang mengalami nekrosis sehingga tidak semua Fusarium yang ditemukan pada jaringan yang nekrosis merupakan patogen. Oleh karena itu untuk mengetahui patogen utama perlu dilakukan uji patogenisitas.

Semua isolat Fusarium yang diuji menimbulkan nekrosis dengan skala yang bervariasi pada bonggol bibit pisang. Patogenisitas dan virulensi cendawan $F$. oxysporum f. sp. cubense pada kerabat pisang berbeda-beda karena adanya perbedaan genotipe di dalam kerabat pisang, juga karena munculnya ras-ras baru $F$. oxysporum f. sp. cubense (Sahlan dan Nurhadi 1996). Terjadinya variasi virulensi di antara ras atau VCG F. oxysporum f. sp. cubense sudah banyak dilaporkan. Beberapa hal yang menyebabkan terjadinya variasi ini ialah adanya pengaruh interaksi inang dengan lingkungan yang bersifat kompleks serta adanya perbedaan karakter biologi, kimia, dan genetik yang dapat memengaruhi faktor-faktor penyebab virulensi seperti reproduksi spora dan produksi toksin (Groenewald 2005).

Hasil penelitian juga menemukan isolat F. solani yang mampu menimbulkan gejala nekrosis pada bonggol tetapi dengan nilai skala nekrosis yang rendah (skala: 1-2). F. solani mempunyai variasi genetik yang sangat tinggi sehingga mempunyai kisaran inang yang luas (Brasileiro et al. 2004). Hingga saat ini belum pernah dilaporkan $F$. solani yang diisolasi dari tanaman pisang bergejala layu dan dapat menimbulkan gejala nekrosis yang mirip dengan gejala yang ditimbulkan F. oxysporum f. sp. cubense pada bonggol bibit pisang. Penelitian ini merupakan laporan pertama yang menyatakan bahwa $F$. solani juga dapat menimbulkan gejala nekrosis pada bonggol bibit pisang. Namun, dikarenakan penelitian ini hanya dilakukan sampai $60 \mathrm{hsi}$ (bibit pisang berumur 3.5 bulan) maka belum dapat dipastikan apakah isolat ini juga mampu menimbulkan gejala layu fusarium yang khas pada saat tanaman pisang memasuki fase generatif.

\section{DAFTAR PUSTAKA}

Aamir S, Sutar S, Singh SK, Baghela A. 2015. $A$ rapid and efficient method of fungal genomic DNA extraction, suitable for PCR based molecular methods. Plant Pathol \& Quarant. 5(2):74-81.

Alabouvette C, Counteaudier Y. 1992. Biological control of Fusarium wilt with nonpathogenic Fusarium. Di dalam: Tjamos EC, Cook RJ, Papavizas GC, editor. Biological Control of Plant Diseases. New York (US): Plenum Press. hlm 415-426..

Altschul SF, Madden TL, Schaffer AA, Zhang J, Zhang Z, Miller W, Lipman DJ.1997. Gapped BLAST and PSI-BLAST: a new generation of protein database search programs. Nucleic Acids Res. 25(17):3389-3402.

Brake VM, Pegg KG, Irwin JAG, Langdon PW. 1990. Vegetative compatibility groups within Australian populations of Fusarium oxysporum f. sp. cubense the cause of Fusarium wilt of bananas. Aust Agric Res. 41(5):863-870. DOI: http://dx.doi.org/ 10.1071/AR9900863.

Brasileiro BTRV, Coimbra MRM, de Morais Jr MAD, Oliveria NTD. 2004. Genetic variability within Fusarium solani species as revealed by PCR-fingerprinting based on PCR markers. Braz J Microbiol. 35(3):205-210. DOI: http://dx.doi.org/ 10.1590/S1517-83822004000200006.

Corderio M. 1994. Scala for Rating the Internal Corm Symtoms Caused by Fusarium Wilt. Honduras (US): INIBAB.

Dita MA, Waalwijk C, Buddenhaguen IW, Souza Jr MT, Kema GHJ. 2010. A molecular diagnosis for tropical race 4 of the banana Fusarium wilt pathogen. Plant Pathol. 59(2):348-357. DOI: http://dx.doi. org/ 10.1111/j.1365-3059.2009.02221.x.

Groenewald S. 2005. Biology, pathogenicity, and diversity of Fusarium oxysporum $\mathrm{f}$. sp. cubense [tesis]. Pretoria (ZA): University of Pretoria.

Hermanto C, Sutanto A, Edison HS, Daniells JW, O’Neill WT, Sinohin VGO, Taylor 
P. 2011. Incidence and distribution of fusarium wilt disease of banana in Indonesia. Di dalam: The V International Symposium on Banana; 2009 September 14; ISHS-ProMusa Symposium on Global Perspectives on Asian Challenges 897. Guangzhou (CH). Hlm. 313-322.

Hwang SC, Ko WH. 2004. Cavendish banana cultivars resistant to Fusarium wilt acquired through somaclonal variation in taiwan. Plant Dis. 88(6):580-588. DOI: http:// dx.doi.org/10.1094/PDIS.2004.88.6.580.

[KEMENTAN] Direktorat Jenderal Hortikultura 2015. Statistik produksi hortikultura 2014. https/hortikultura. pertanian.go.id/w p-content / uploads/2016/02/Statistik-Produksi-2014. pdf [diakses 5 April 2017].

Kistler HC. 1997. Genetic diversity in the plant-pathogenic fungus Fusarium oxysporum. Phytopathol. 87:474479. DOI: http://dx.doi.org/10.1094/ PHYTO.1997.87.4.474.

Leslie JF, Summerell BA. 2006. The Fusarium Laboratory Manual. Ed ke-1. Oxford (GB): Blackwell. DOI: http://dx.doi. org/10.1002/9780470278376.

LinYH, Chang JY,LiuET, Huang JW and Chang PFL. 2009. Development of a molecular marker for specific detection of Fusarium oxysporum f. sp. cubense race 4. Eur J Plant Pathol. 123(3):353-365. DOI: http:// dx.doi.org/10.1007/s10658-008-9372-4.

Martin JP. 1950. The use of acid, rose bengal and streptomycin in the plate method for estimating soil fungi. SOiZ Sci. 69:215-232.

Moore NY, Pegg KG, Allen RN, Irwin JAG. 1993. Vegetative compatibility and distribution of Fusarium oxysporum f. sp. cubense in Australia. J Austr Expt Agric. 33(6):792-802. DOI: http://dx.doi. org/10.1071/ea9930797 .

O'Donnell K, Sutton DA, Fothergill A, Mc Carthy D, Rinaldi MG, Brandt ME, Zhang N, Geiser DM. 2008. Molecular phylogenetic diversity, multilocus haplotype nomenclature, and in vitro antifungal resistance within the Fusarium solani species complex. J Clin Microbiol. 46(8):2477-2490. DOI: http://dx.doi.org/ 10.1128/JCM.02371-07.

Ploetz RC. 1990. Variability in Fusarium oxysporum f. sp. cubense. Can J Bot. 68(6):1357-1363. DOI: http://dx.doi. org/10.1139/b90-173.

Ploetz RC. 2006. Fusarium wilt of banana is caused by several pathogens referred to as Fusarium oxysporum f. sp. cubense. Phytopathol. 96(6):653-656. DOI: http:// dx.doi.org/10.1094/PHYTO-96-0653.

[Pusdatin] Pusat Data dan Sistem Informasi Pertanian. 2014. Outlook Komoditi Pisang. http://epublikasi.setjen.pertanian. go.id/epublikasi/outlook/epublikasi/ outlook/2014 [diakses10 Sep 2016].

Sahlan, Nurhadi, Hermanto C. 1996. Penyakitpenyakit utama tanaman pisang. Di dalam: Purnamo S, editor. Solok (ID): Balai Penelitian Tanaman Buah.

Stover RH, Buddenhagen IW. 1986. Banana breeding: polyploidy, disease resistance and productivity. Fruits 41(3):175-191.

Tamura K, Stecher G, Peterson D, Filipski A, Kumar S. 2013. MEGA6: molecular evolutionary genetics analysis version 6.0. Mol Biol Evolution. 30(12):2725-2729. DOI: http://dx.doi.org/10.1093/molbev/ mst197 .

White TJ, Bruns T, Lee S, Taylor JW. 1990. Amplification and direct sequencing of fungal ribosomal rna genes for phylogenetics. Di dalam: Innes MA, Gelfand DH, Sninsky JJ, White TJ, editor. PCR Protocols: A Guide of Methods and Applications. New York (US): Academic Press. DOI: http://dx.doi.org/10.1016/ B978-0-12-372180-8.50042-1.

Williams RC, Hermanto C, Suwanda, Komolong B, Kokoa P. 2010. Mitigating the threat of banana Fusarium wilt: understanding the agroecological distribution of pathogenic forms and developing disease management strategies. Final report. HORT/2005/136. Canberra (AU): ACIAR. 